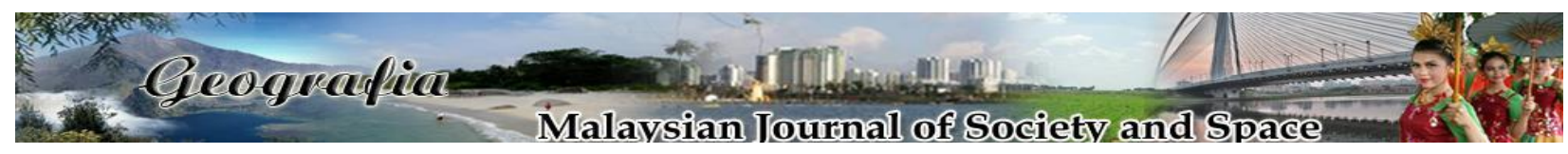

\title{
Kecenderungan politik pengundi luar Kelantan di Lembah Klang pasca PRU-14: Suatu pemerhatian kritikal
}

\author{
Mazli Mamat ${ }^{1}$, Mohd Rahimi Ramli ${ }^{2}$ \\ ${ }^{1}$ Jabatan Pengajian Kenegaraan dan Ketamadunan, Fakulti Ekologi Manusia, Universiti Putra Malaysia \\ ${ }^{2}$ Pusat Sains Kemanusiaan, Universiti Malaysia Pahang
}

Correspondence: Mazli Mamat (email: mazlimamat@gmail.com)

Received: 24 May 2021; Accepted: 19 July 2021; Published: 27 August 2021

\begin{abstract}
Abstrak
Pengundi luar merupakan salah satu golongan yang memberi sumbangan penting terhadap kemenangan PAS di Kelantan kerana ramai pengundi luar Kelantan yang layak mengundi akan pulang untuk mengundi setiap kali berlakunya pilihan raya. Namun, proses sosialisasi politik dan tahap kehidupan yang dinikmati khususnya di Lembah Klang berbeza dengan kehidupan realiti di Kelantan. Oleh itu, kajian ini bertujuan untuk mengenal pasti kecenderungan politik pengundi luar Kelantan yang menetap di Lembah Klang. Kajian ini dilakukan melalui pendekatan kajian kuantitatif menerusi kaedah tinjauan di lapangan dan secara atas talian dengan menggunakan borang soal selidik sekitar bulan Mac 2020 hingga Disember 2020. Kajian ini dilakukan di sekitar Lembah Klang meliputi Wilayah Persekutuan Kuala Lumpur dan beberapa kawasan sekitar Negeri Selangor. Kaedah kajian yang digunakan ialah kaedah persampelan bebola salji (Snowball) dan persampelan mudah. Responden yang terlibat dalam kajian ini adalah seramai 403 orang responden. Data kajian ini dianalisis secara statistik deskriptif. Hasil kajian mendapati majoriti responden bukan ahli mana-mana parti politik dan mereka cenderung memilih PAS di peringkat DUN dan Parlimen. Selain itu, tiada perubahan yang signifikan antara kecenderungan politik mereka ini dengan tempoh menetap di Lembah Klang. Oleh itu, jelaslah bahawa pengundi luar Kelantan merupakan simpanan tetap kepada parti PAS di Kelantan. Justeru, faktor yang dikaitkan agama Islam yang menjadi asas pemilihan PAS masih menebal dalam diri pengundi luar Kelantan di Lembah Klang. Dengan ini, jelaslah bahawa pengundi luar Kelantan beridentifikasi terhadap parti PAS yang menepati aspirasi politik mereka.
\end{abstract}

Kata Kunci: Budaya politik, kecenderungan, konfigurasi, nilai islam, pengundi luar, pilihan raya 


\title{
The political tendency among Kelantanese voters residing in the Klang Valley post GE-14: A critical observation
}

\begin{abstract}
Voters residing in other states have been one of the major contributers towards PAS victory in Kelantan, due to the facts that many eligible voters residing outside of Kelantan will return to the state to cast their vote when there is an election. However, the process of political socialization and living standards enjoyed by these voters, especially in the Klang Valley area is different from the reality of life in Kelantan. Therefore, this research aims to identify the political preferences of voters residing outside of Kelantan, particularly in the Klang Valley. This research was conducted through the quantitative research approach by utilizing the field study method and online method by using questionnaires distributed from March 2020 until December 2020. This research was conducted in the Klang Valley area, consisting of the Federal Territory of Kuala Lumpur and a certain area around the state of Selangor. The sampling method utilized for this research was 'Snowball' Sampling and convenience sampling. A total of 403 were respondents were involved in this research. The data of this research was analyzed through descriptive statistics. This research found that majority of the respondents were not members of any political party and they preferred to choose PAS for DUN and Parliament seats. Moreover, there were no significant changes between the respondent's political preferences' and the duration of their stay in Klang Valley. Therefore, it is clear that voters residing outside of Kelantan are permanent vote reserves for PAS in Kelantan. Thus, factors that relate to Islam, which become the primary reason to choose PAS are still dominant among voters residing outside of Kelantan in the Klang Valley. Thus, it is evident that the voters outside Kelantan identify with the PAS party which meets their political aspirations.
\end{abstract}

Keywords: Political culture, tendency, configuration, islamic values, voters residing outside, elections

\section{Pengenalan}

Sejak sekian lama kemenangan sesebuah parti politik di Kelantan bukan sahaja ditentukan oleh pengundi yang bermastautin di dalam Negeri Kelantan, tetapi turut ditentukan oleh pengundi yang bermastautin di luar dari Negeri Kelantan. Rakyat Kelantan berhijrah keluar dari Negeri Kelantan atas pelbagai sebab antaranya mengikut ahli keluarga, meningkatkan sosioekonomi, melanjutkan pengajian, tuntutan kerjaya dan suasana terhimpit akibat kemiskinan di Kelantan (Amer Saifude, 2013). Kawasan yang menjadi tumpuan golongan berhijrah ini adalah negeri yang lebih maju seperti di Lembah Klang disebabkan peluang pekerjaan, pendidikan dan pelbagai kemudahan lain yang telah tersedia di kawasan tersebut.

Bagi golongan berhijrah, walaupun mereka bekerja dan bermastautin di bandar, terdapat sebilangan daripada mereka yang masih mengundi di tempat asal, iaitu di Kelantan dan golongan pengundi jenis ini didefinisikan sebagai pengundi luar. Golongan pengundi jenis ini adalah dalam kalangan yang mengundi di kawasan yang bukan mengikut alamat tempat tinggal semasa mereka. Contohnya, seorang pengundi berdaftar di Kelantan telah bermastautin di Lembah Klang, tetapi masih tetap mengundi di Kelantan disebabkan tidak mengemaskini alamat mengundi mengikut 
tempat tinggal semasa. Golongan pengundi inilah yang dimaksudkan sebagai pengundi luar Kelantan dalam konteks kajian ini. Dalam hal ini, tiada sebarang peruntukan undang-undang yang boleh mewajibkan setiap pengundi untuk menukar alamat kawasan mengundi mengikut tempat tinggal semasa, jika sekiranya pengundi itu sendiri tidak mahu mengemaskini alamat mengikut tempat tinggal semasa mereka. Oleh sebab itu, mereka yang dikenali sebagai pengundi luar ini akan terus wujud selagi tiada undang-undang yang boleh dikuatkuasakan untuk mengekang fenomena tersebut daripada terus berlaku.

Tingkah laku politik pengundi luar sukar untuk dijelaskan apabila kekurangan kajian secara empirikal yang dijalankan untuk memahami dan mengetahui kecenderungan politik, budaya politik dan nilai politik yang menjadi keutamaan pengundi luar. Tambahan pula sewaktu kempen pilihan raya, janji pilihan raya, penyelesaian isu tempatan hanya berlangsung di kawasan pilihan raya terbabit sahaja dan dalam masa yang sama pengundi luar tiada di kawasan tersebut. Situasi ini menyebabkan citra politik pengundi luar tidak mendapat perhatian. Bagi parti politik, pengundi luar ini tinggal di merata tempat dan sukar bagi mereka untuk mendampingi dan mendekati setiap pengundi terbabit.

Pengundi luar Kelantan ini membawa sentimen budaya politik berbeza dengan budaya politik pengundi yang bermastautin di Kelantan. Walau bagaimanapun, budaya politik pengundi luar ini adalah bersifat konfigurasi di mana budaya politik tersebut menjadi pelengkap dalam membentuk budaya politik secara keseluruhan pengundi Kelantan. Kehadiran pengundi luar dalam setiap pilihan raya memberi kesan yang signifikan terhadap kemenangan PAS di Kelantan. Hal ini kerana pengundi luar Kelantan akan kembali ke Kelantan bagi setiap kali berlakunya pilihan raya. Jumlah pengundi Kelantan yang tinggal di luar Negeri Kelantan agak ramai dan pengundi ini didapati mampu mempengaruhi kemenangan calon dan parti yang bertanding seperti telah dibuktikan dalam beberapa pilihan raya sebelum ini. Akhbar Sinar Harian (27 Feb 2017) melaporkan Dr Ahmad Zahid Hamidi, Presiden UMNO melahirkan kebimbangan terhadap kesan kehadiran pengundi luar. Menurut beliau, pengundi luar membawa sentimen politik yang berbeza dengan pengundi tempatan dan mereka berupaya mempengaruhi ahli keluarga terdekat untuk menolak dan menafikan kemenangan BN. Sementara itu, akhbar Harian Metro (10 Mei 2018) melaporkan Ahmad Yakob, Menteri Besar Kelantan mengakui pengundi luar Kelantan memberi sumbangan signifikan terhadap kemenangan PAS di Kelantan dalam Pilihan Raya Umum (PRU) ke-14 yang lalu.

Menyingkap kembali keputusan PRU terdahulu terutama dalam PRU ke-11, kedudukan PAS sedikit tergugat dan pengaruhnya didapati mulai merosot. Hal ini berlaku ekoran pertukaran kepimpinan negara daripada Dr Mahathir Mohamad kepada Tun Abdullah Ahmad Badawi. Pelbagai pihak beranggapan pada PRU ke-12, pengundi Kelantan akan menukar parti pemerintah dengan menolak Kerajaan PAS yang didakwa tidak mampu membawa pembangunan kepada Kerajaan BN yang lebih berkeupayaan membawa kemajuan di Kelantan (Mohd Mahadee \& Ab. Bassit, 2008). Namun, apa yang berlaku jauh dari jangkaan semua pihak apabila PAS telah berjaya memposisikan kembali dan memperkukuhkan kedudukan di Kelantan bersama dengan parti gabungan PR dalam PRU ke-12. Dalam PRU ke-13 pula, BN tetap masih tidak berjaya meraih sokongan yang mencukupi untuk membentuk kerajaan, walaupun terdapat penambahan bilangan kerusi yang dimenangi. Faktor karismatik almarhum Nik Abdul Aziz Nik Mat dan kegagalan strategi Gelombang Merah (Mohd Faidz et al., 2014) telah merencatkan sekali lagi harapan BN di Kelantan. Namun Nazri Noor (2015), menyifatkan kemenangan PAS di Kelantan juga disebabkan sikap orang Melayu Kelantan yang membawa sentimen anti-establishment, tidak takut mengambil risiko serta ghairah terhadap politik. 
Seterusnya, dalam PRU ke-14, PAS tetap berjaya mempertahankan kemenangannya di Kelantan malah berhasil menambah kerusi apabila memenangi 37 kerusi dan UMNO hanya menang 8 kerusi. Kejayaan ini menandakan PAS telah memerintah Kelantan untuk penggal ketujuh secara berturut-turut. Survival politik PAS menyerlahkan 'keunikan' dan keistimewaan Kelantan yang sudah semestinya menarik untuk dirungkai tentang apa sebenarnya yang dimahukan oleh pengundi Kelantan terutamanya pengundi luar yang didakwa sebagai simpanan tetap PAS serta elemen yang membentuk budaya politik mereka sehingga dikatakan sukar diramal dan bersikap matang dalam berpolitik (Mohd Mahadee \& Ab. Bassit, 2008). Adakah benar pengundi luar Kelantan masih menjadi simpanan tetap PAS? Sejauh mana tahap penglibatan politik pengundi luar Kelantan terutama dalam menjadi ahli parti politik? Hal ini penting kerana mereka merupakan konfigurasi kepada budaya politik Kelantan secara keseluruhannya. Oleh itu, matlamat utama kajian adalah untuk mengenal pasti kecenderungan politik pengundi luar Kelantan di Lembah Klang pasca PRU Ke-14.

\section{Sorotan literatur}

Dalam PRU Ke-14 yang lalu, reputasi AMANAH dan BERSATU di Kelantan didapati tidak mempunyai kekuatan untuk menggugat penguasaan UMNO dan PAS. Hal ini kerana, walaupun dipimpin oleh bekas pemimpin utama PAS dan UMNO, parti AMANAH dan BERSATU tidak berupaya untuk memenangi sebarang kerusi dalam PRU ke-14 di Kelantan. Ini kerana, orang Melayu Kelantan melihat dua parti sahaja yang layak diberi kepercayaan, iaitu PAS atau UMNO (Mohd Mahadee \& Ab. Bassit, 2008; Yazid Saleh et al. 2020) dan parti lain didapati sukar untuk mendapat tempat di Kelantan.

UMNO dan PAS sering kali digambarkan sebagai sebuah parti yang bertentangan dari sudut ideologi dan juga dianggap sebagai seteru tradisi. Namun persamaan kedua-dua parti ini, kumpulan sasar mereka adalah sama, iaitu orang Melayu (Ghazali Mayudin, 2005). Setelah UMNO tidak lagi berada ditampuk kuasa kerana tewas mengejut kepada PH pada tanggal 9 Mei 2018, kedua-dua parti mula menjalinkan kerjasama. Hasilnya kerjasama PAS dan UMNO menerusi Muafakat Nasional dalam beberapa PRK telah memberikan impak positif apabila orang Melayu mula kembali memberi sokongan kepada parti Melayu terbabit. Namun, perkembangan muktahir menampakkan telah mula wujudnya bibit-bibit keretakkan apabila PAS secara rasmi menyertai PN dan dalam masa yang sama mahu kekal bersama UMNO dalam Muafakat Nasional.

Berdasarkan kepada realiti politik semasa, perbincangan dalam kajian ini akan terarah kepada persaingan politik di Kelantan hanya melibatkan PAS dan UMNO. Hal ini kerana, walaupun PAS dan UMNO menjalinkan kerjasama, namun di peringkat negeri persaingan antara kedua-dua parti masih berlangsung tetapi dalam keadaan yang lebih harmoni. Dalam pentadbiran di Kelantan, PAS telah menawarkan pakej politik yang lengkap kepada rakyat melalui manifesto bertemakan 'Membangun Bersama Islam' (MBI). Manifesto tersebut merupakan satu slogan yang digunakan ke arah menjana dan merealisasikan hasrat pelaksanaan undang-undang Islam secara menyeluruh dalam urusan politik dan pentadbiran. Slogan ini juga bermaksud maju ke hadapan dengan cara yang tidak bercanggah dengan tuntutan agama Islam (Shukeri et al. 2011). MBI berpaksikan kepada tiga teras, iaitu Mas'uliyah, Ubudiah dan Itqan (Wan Nik, 2015). MBI tidak memerlukan idea besar seperti 'tamadun' kerana MBI telah sedia ada dalam Islam, cuma yang perlu diikhtiarkan adalah bagaimana untuk mengoperasikan syariat Islam serta merealisasikannya secara optimum berdasarkan kepada waq'ie masyarakat setempat dan keterbatasan sumber yang 
ada (Riduan Muhamad Nor, 2015). Slogan MBI menjadi pelengkap kepada dasar PAS, iaitu 'Kepimpinan Ulama' yang menjadi tonggak perjuangan Islam (Wan Nik, 2015) telah memandu kerajaan Kelantan mentadbir negeri tersebut.

Selain itu, PAS didapati menjadikan Islam sebagai asas bagi kekuatan mereka, UMNO pula, menjadikan bangsa Melayu sebagai asas kekuatan politik mereka. Antara dua asas tersebut, orang Kelantan melihat kepentingan 'Islam' lebih utama dari kepentingan 'Melayu' (Mohd Mahadee \& Ab. Bassit, 2008). Kajian Junaidi (2017) di Parlimen Pasir Mas mendapati pengundi membuat pilihan untuk kekal di bawah pemerintahan PAS walaupun parti itu gagal membawa kemajuan kerana mereka mahukan keredhaan Allah dalam bernegara. Selain itu, kajian oleh Mohd Faidz et al. (2014) juga mendapati faktor yang mendorong $\mathrm{BN}$ terus ditolak oleh pengundi Kelantan dalam PRU ke-13 adalah disebabkan karismatik Nik Abdul Aziz Nik Mat, kegagalan Gelombang Merah dan sokongan padu daripada pengundi luar kepada PAS.

Sementara itu, pengundi luar yang menetap di Kuala Lumpur didapati lebih tertarik dengan janji yang dibuat oleh PR seperti penghapusan tol, PTPTN dan penurunan harga kereta (Mohd Faidz et al., 2014) berbanding janji oleh BN. Rakyat Kelantan juga tidak mempercayai janji BN untuk menyelesaikan masalah air. Selain itu, pengundi luar Kelantan juga didapati lebih berminat sekiranya BN menawarkan penyelesaian kemiskinan di Kelantan dan bukannya menumpukan kepada pembangunan fizikal semata-mata. Walau bagaimanapun, tawaran tersebut juga berdepan kesukaran kerana keinginan kuat rakyat untuk mengekalkan kepimpinan ulama bagi meneruskan pentdbiran di Kelantan (Mohd Faidz et al 2014).

Dalam pentadbiran PAS di Kelantan turut ditekankan tentang penyediaan sistem perundangan Islam, peningkatan aktiviti dakwah dan penghayatan secara menyeluruh Islam, penyelarasan aktiviti ekonomi dan kewangan mengikut prinsip Islam, pengukuhan sistem pendidikan Islam dan penerapan konsep kepimpinan ulama (Shukeri et al. 2011). Arkitek yang menjadikan Islam sebagai cara hidup di Kelantan adalah Nik Abdul Aziz Nik Mat, Menteri Besar Kelantan ke-6 yang menjawat jawatan tersebut selama 23 tahun. Jika dilihat dalam kajian Junaidi Awang Besar (2021) di DUN Chempaka, masyarakat didapati mengutamakan kriteria parti politik dengan tambahan kebolehan calon yang mengutamakan rakyat berbanding faktor isu, manifesto, konflik dan sebagainya. Kriteria calon yang diutamakan ialah jujur, amanah, bertanggungjawab, bersih daripada rasuah dan pemimpin yang mengutamakan rakyat sebagai pertimbangan penting dalam pemilihan. Jelas disini dominasi kepartian masih diutamakan serta digabung dengan kriteria calon selepasnya.

Selain itu, Junaidi Awang Besar et al., (2020) dalam kajiannya berkaitan pola sokongan belia Melayu dalam PRU-14 di negeri Kedah mendapati generasi baru Melayu telah berubah di mana sifat feudal dalam diri mereka mulai mencair, generasi baru luar bandar tidak lagi mengambil kisah tentang kesetiaan kepada sesebuah parti tetapi memilih berasaskan kebaikan negara. Malah, di Felda pada sebelum ini menjadi kawasan deposit BN tetapi pada PRU-14 undi pengundi di Felda yang terdiri daripada pengundi Melayu tidak lagi berpihak kepada BN (Mohammad Agus Yusoff \& Shah Mohd Akmal Abdul Halim, 2019). Keadaan ini menunjukkan perubahan budaya telah berlaku dan kajian Mohd Mahadee Ismail et al, (2020) telah mendapati telah lahir budaya politik yang lebih terbuka dan para pengundi semakin matang dalam membuat penilaian terhadap perkembangan politik.

Sementara itu, dalam konteks kajian mengenai pengundi luar di luar negara ianya berbeza dengan konsep pengundi luar dalam konteks kajian ini kerana perbezaan struktur politik dan sistem pilihan raya di setiap negara. Walau bagaimanapun kajian yang seakan-akan mirip dengan konsep pengundi luar dalam konteks kajian ini ialah kajian tentang pengundi yang tinggal di luar negeri 
yang dikenali sebagai 'oversea voters'. Persamaan antara 'oversea voters' dan pengundi luar ialah kedua-dua golongan pengundi ini bermastautin di luar kawasan tempat mereka mengundi dan mereka mendapat manfaat politik di luar daripada kawasan mereka membuang undi. Tingkah laku mengenai 'oversea voters' dapat dilihat menerusi kajian yang dijalankan oleh Imai dan King (2004); Simone dan Bruno (2008) Jaca dan Torneo (2019) serta Sebastian dan Regis (2021). Dalam kajian tersebut, didapati mereka telah mendukung prinsip yang sama dengan kajian mengenai konsep pengundi luar dalam kajian ini, iaitu mereka memberi penekanan terhadap kecenderungan, pola pengundian, perbezaan aspirasi politik dan faktor penentu pengundi dalam kalangan 'oversea vortes' keluar mengundi. Oleh yang demikian, kajian mengenai pengundi luar boleh dianggap sebagai kajian menggunakan konsep yang sama dengan 'oversea vortes' bersifat konfigurasi dalam budaya politik dan memberi kesan kepada pola pengundian dalam sesebuah pilihan raya.

Berdasarkan perbincangan mengenai situasi politik di Kelantan, jelas menunjukkan Kerajaan Negeri bertindak menanam nilai politik Islam dalam kehidupan harian rakyat. Dengan pendekatan Islam ini telah menjadikan PAS bertambah selesa untuk mengukuhkan pengaruh bagi mengekalkan sokongan. Kesimpulannya, pengundi dari bandar atau pengundi luar ini memberi sumbangan yang signifikan ke atas kejayaan PAS dalam mengekalkan penguasaan di Kelantan. Banyak faktor yang menjadi pendorong kepada tingkah laku sedemikian antaranya disebabkan sumber maklumat dan faktor persekitaran di sekeliling kehidupan mereka.

\section{Metodologi kajian}

Penyelidikan ini menggunakan pendekatan kuantitatif menerusi kaedah tinjauan di lapangan dan secara atas talian kerana pada ketika ini negara Malaysia diancam pandemik Covid-19. Pengumpulan data dilakukan sekitar bulan Mac 2020 hingga Disember 2020. Bagi kaedah atas talian, pengkaji menghubungi secara terus semua responden untuk mendapatkan data. Kajian ini dilakukan di sekitar Lembah Klang meliputi Wilayah Persekutuan Kuala Lumpur dan beberapa kawasan sekitar Negeri Selangor. Kajian dijalankan di Lembah Klang disebabkan kawasan ini merupakan yang paling maju di Malaysia dan mempunyai budaya politik lebih dinamik serta bersifat rencam berbanding di Kelantan. Kaedah kajian yang digunakan ialah persampelan bebola salji (Snowball) dan persampelan mudah. Berdasarkan Krejcie dan Morgan (1970), saiz sampel dalam kajian ini adalah seramai 403 orang responden yang mewakili jumlah populasi pengundi luar Kelantan di Lembah Klang. Selepas data siap dikumpul, data kemudian dianalisis secara deskriptif dengan menggunakan Aplikasi SPSS.

\section{Dapatan kajian dan perbincangan}

\section{Latar belakang demografi}

Taburan responden mengikut pecahan umur, responden dalam kajian ini dipecahkan kepada enam kategori umur, bermula dengan kumpulan umur paling bawah, iaitu responden yang berumur 21 hingga 30 tahun dan yang paling akhir sekali ialah responden yang berumur 61 tahun dan ke atas. Jadual 1 memaparkan pecahan umur responden mengikut pecahan kategori seperti yang dinyatakan di atas. 
Jadual 1. Umur responden.

\begin{tabular}{ccc}
\hline Umur & Bilangan $(\mathbf{n})$ & Peratus $(\%)$ \\
\hline 21-30 tahun & 114 & 28.3 \\
$31-40$ tahun & 211 & 52.4 \\
$41-50$ tahun & 66 & 16.4 \\
$51-60$ tahun & 10 & 2.5 \\
61 tahun ke atas & 2 & 0.5 \\
\hline
\end{tabular}

Sumber: Kerja Lapangan 2020

Berdasarkan Jadual 1 menunjukkan responden yang paling ramai dalam kajian ini adalah dari kategori responden yang berumur 31 hingga 40 tahun, iaitu seramai 211 orang (52.4\%), diikuti dengan responden berumur 21 hingga 30 tahun, iaitu seramai 114 (28.3\%). Manakala yang berumur 41 hingga 50 tahun adalah seramai 66 orang (16.4\%). Responden yang berumur 51 hingga 60 tahun adalah seramai 10 orang $(2.5 \%)$ dan responden berumur 61 tahun ke atas seramai 2 orang $(0.5 \%)$. Berdasarkan maklumat yang dipaparkan dalam Jadual 1 di atas, didapati sebilangan besar responden terdiri daripada mereka yang berumur antara 21 hingga 40 tahun yang membentuk kirakira 80.7 peratus daripada jumlah keseluruhan. Lingkungan umur sedemikian ini dirujuk sebagai golongan pengundi muda (Yazid Saleh et al., 2020).

\section{Tahap pendidikan}

Dalam kajian ini juga, turut diambil kira berkenaan taburan responden mengikut tahap pendidikan. Dapatan taburan responden mengikut pecahan tahap pendidikan tertinggi adalah sebagaimana yang ditunjukkan dalam Jadual 2.

Jadual 2. Tahap pendidikan.

\begin{tabular}{ccc}
\hline Tahap Pendidikan & Bilangan (n) & Peratus (\%) \\
\hline SRP/ PMR & 12 & 3.0 \\
SPM/ SMU & 66 & 16.4 \\
STPM/ STAM/ Diploma & 114 & 28.3 \\
Sarjana Muda & 167 & 41.4 \\
Sarjana dan ke atas & 40 & 9.9 \\
Kelulusan-kelulusan lain & 4 & 1.0 \\
\hline
\end{tabular}

Sumber: Kerja Lapangan 2020

Jadual 2 menunjukkan taburan responden mengikut pecahan tahap pendidikan tertinggi. Responden yang paling ramai dalam kajian ini ialah mereka yang berkelulusan Sarjana Muda, iaitu seramai 167 orang (41.4\%). Manakala responden yang berkelulusan peringkat STPM, STAM dan Diploma adalah seramai 114 orang $(28.3 \%)$ diikuti dengan responden yang berkelulusan peringkat SPM, SMU seramai 66 orang (16.4\%). Sementara itu, responden yang berkelulusan SRP dan PMR adalah seramai 12 orang (3.0\%). Manakala responden yang mempunyai kelulusan-kelulusan lain pula adalah terdiri daripada mereka yang berkelulusan peringkat sijil kemahiran, iaitu seramai 4 orang $(1.0 \%)$. 


\section{Tempoh menetap}

Selain itu, kajian ini juga turut memperincikan tempoh masa responden menetap di Lembah Klang bagi melihat perubahan yang berlaku. Untuk itu, lima kategori telah ditetapkan dalam kajian ini, iaitu dimulakan dengan tempoh masa 1 hingga 5 tahun, diikuti dengan tempoh 6 hingga 10 tahun, 11 hingga 15 tahun dan 16 hingga 20 tahun. Kategori tempoh menetap yang terakhir adalah kumpulan yang lebih dari 20 tahun. Jadual 3 merupakan ringkasan dapatan mengikut tempoh masa menetap di Lembah Klang.

Jadual 3. Tempoh menetap di luar Kelantan.

\begin{tabular}{ccc}
\hline Tempoh Menetap & Bilangan $(\mathbf{n})$ & Peratus $(\%)$ \\
\hline 1-5 tahun & 112 & 27.8 \\
6-10 tahun & 98 & 24.3 \\
11-15 tahun & 89 & 22.1 \\
16-20 tahun & 52 & 12.9 \\
Lebih 20 tahun & 52 & 12.9 \\
\hline
\end{tabular}

Sumber: Kerja Lapangan 2020

Jadual 3 menunjukkan taburan tempoh masa responden menetap di Lembah Klang. Jumlah responden yang paling ramai adalah responden yang tinggal dalam tempoh antara 1 hingga 5 tahun, iaitu seramai 112 orang (27.8\%). Manakala bilangan responden yang paling sikit adalah responden yang tinggal dalam tempoh antara 16 hingga 20 tahun dan responden yang tinggal lebih daripada 20 tahun, iaitu masing-masing seramai 52 orang (12.9\%). Sementara itu, responden yang tinggal dalam tempoh antara 6 hingga 10 tahun adalah seramai 98 orang $(24.3 \%)$ dan responden yang tinggal dalam tempoh 11 hingga 15 tahun adalah seramai 89 orang (22.1\%).

\section{Keahlian dalam parti politik}

Dalam kajian ini, turut diselidiki mengenai keahlian responden dalam parti politik. Tujuannya adalah untuk melihat sejauh mana responden dalam kajian ini mengambil bahagian dalam politik dan menjadi ahli dalam mana-mana parti politik. Keahlian dalam parti politik ini merupakan salah satu ciri dalam penyertaan politik. Jadual 4 merupakan pecahan dari keahlian responden dalam parti politik sama ada menjadi ahli atau sebaliknya. Jika responden tersebut menjadi ahli parti, apakah jawatan yang disandang oleh responden dalam parti politik terbabit. Perincian pecahan taburan mengikut keahlian dalam parti politik seperti Jadual 4.

Jadual 4. Keahlian responden dalam parti politik

\begin{tabular}{ccc}
\hline Status & Bilangan (n) & Peratus (\%) \\
\hline Bukan Ahli & 325 & 80.6 \\
Ahli biasa yang pasif & 48 & 11.9 \\
Ahli biasa yang aktif & 20 & 5.0 \\
AJK Cawangan Parti & 6 & 1.5 \\
AJK Pusat Parti & 4 & 1.0 \\
\hline
\end{tabular}

Sumber: Kerja Lapangan 2020

Jadual 4 menunjukkan keahlian responden dalam parti politik. Sebahagian besar responden, iaitu 325 orang $(80.6 \%)$ didapati tidak menyertai mana-mana parti politik. Manakala 
responden yang menyertai parti politik pula hanya menjadi ahli biasa yang pasif, iaitu seramai 48 orang (11.9\%), diikuti dengan ahli biasa yang aktif, 20 orang (5.0\%), AJK Cawangan Parti 6 orang (1.5\%) dan AJK Pusat Parti 4 orang (1.0\%). Berdasarkan kepada dapatan yang ditunjukkan jelas dapat disimpulkan bahawa responden dalam kajian ini sebahagian besarnya tidak menjadi ahli mana-mana parti politik. Kalau adapun, hanyalah ahli biasa yang pasif.

\section{Kecenderungan sokongan pengundi luar Kelantan}

Pilihan raya merupakan cara rakyat memilih dan memberikan mandat kepada parti politik untuk memerintah sekali gus menentukan dasar dan perjalanan pentadbiran negeri dan negara. Malaysia menggunakan sistem pilihan raya pelbagai parti di mana parti politik yang berdaftar boleh menubuhkan kerajaan jika memperoleh majoriti kerusi di Parlimen atau Dewan Undangan Negeri. Sistem pengundian yang diamalkan adalah first-past the post, iaitu seseorang calon akan dianggap memenangi pilihan raya bagi suatu kawasan apabila memperoleh majoriti mudah. Bagi mengetahui arah sokongan responden atau kecenderungan sokongan politik dalam kajian ini. Jadual 5 merupakan perincian dapatan arah sokongan responden.

Jadual 5. Arah sokongan responden

\begin{tabular}{ccc}
\hline Pilihan Sokongan & \multicolumn{2}{c}{ Pilihan Responden } \\
\cline { 2 - 3 } & Parlimen & DUN \\
\hline PAS & $219(54.3 \%)$ & $250(62.0 \%)$ \\
BN & $115(28.5)$ & $81(20.1 \%)$ \\
PH & $35(8.7 \%)$ & $35(8.7 \%)$ \\
Bebas & $24(6.0 \%)$ & $29(7.2 \%)$ \\
Tidak Mengundi & $10(2.5 \%)$ & $8(2.0 \%)$ \\
\hline
\end{tabular}

Sumber: Kerja Lapangan 2020

Jadual 5 menunjukkan arah sokongan, responden didapati lebih cenderung menyokong PAS di kawasan Parlimen dan juga DUN. Seramai 219 orang (54.3\%) responden menyatakan mereka akan mengundi PAS di kawasan Parlimen, berbanding responden yang akan mengundi BN adalah seramai 115 orang (28.5\%). Sementara itu, responden yang akan mengundi PH adalah seramai 35 orang (8.7\%), Bebas 24 orang (6.0\%) dan Tidak Mengundi 10 orang (2.5\%). Manakala di peringkat DUN, seramai 250 (62\%) akan memberi undi kepada PAS, 81 orang (20.1\%) akan mengundi BN, 35 orang (8.7\%) akan mengundi PH, 29 orang (7.2\%) akan mengundi Bebas dan 8 orang $(2.0 \%)$ pula Tidak Mengundi.

Hasil dapatan yang ditunjukkan dalam Jadual 5 memberi gambaran bahawa pengundi luar Kelantan di Lembah Klang lebih cenderung mengundi PAS berbanding parti lain. Maka tidak hairanlah dari tahun 1990 sehinggalah sekarang, PAS menganggap bahawa pengundi luar ini sebagai simpanan tetap mereka untuk terus kekal memerintah Kelantan (Ab. Rahim, 1995). Dalam sejarah persaingan politik di Kelantan, hanya UMNO merupakan satu-satunya parti politik yang paling memberi saingan kepada PAS dan ini dapat dibuktikan apabila UMNO pernah berjaya menguasai Kelantan (Mazlan, 1998). Misalnya dalam PRU Ke-14, PH melalui gabungan mereka, iaitu AMANAH cuba menyaingi PAS, namun AMANAH gagal dan tidak berupaya untuk menafikan pengaruh PAS di Kelantan walaupun pemimpin AMANAH dibarisi oleh bekas pemimpin besar PAS. 


\section{Kecenderungan sokongan terhadap parti mengikut tempoh menetap}

Jadual 6 merupakan pecahan undi parlimen, manakala Jadual 7 merupakan pecahan undi DUN berdasarkan kepada tempoh menetap di Lembah Klang. Tujuan analisis crosstabs ini dijalankan adalah untuk melihat sama ada wujud perbezaan antara pecahan undi mengikut parlimen dan DUN berdasarkan tempoh masa menetap.

Jadual 6. Kecenderungan sokongan di peringkatparlimen berdasarkan tempoh menetap.

\begin{tabular}{cccccc}
\hline \multirow{2}{*}{ Tempoh Menetap } & \multicolumn{4}{c}{ Kecenderungan Sokongandi Peringkat Parlimen } \\
\cline { 2 - 6 } & PH & BN & PAS & Bebas & Tidak Mengundi \\
\hline 1-5 tahun & $7(6.3 \%)$ & $27(24.1 \%)$ & $66(58.9 \%)$ & $12(10.7 \%)$ & - \\
6-10 tahun & $10(10.2 \%)$ & $30(30.6 \%)$ & $48(49.0 \%)$ & $6(6.1 \%)$ & $4(4.1 \%)$ \\
11-15 tahun & $8(9.0 \%)$ & $26(29.2 \%)$ & $47(52.8 \%)$ & $2(2.2 \%)$ & $6(6.7 \%)$ \\
16-20 tahun & $6(11.5 \%)$ & $18(34.6 \%)$ & $28(53.8 \%)$ & - & - \\
Lebih 20 tahun & $4(7.7 \%)$ & $14(26.9 \%)$ & $30(57.7 \%)$ & $4(7.7 \%)$ & - \\
\hline
\end{tabular}

Sumber: Kerja Lapangan 2020

Jadual 6 menunjukkan kecenderungan sokongan di peringkat parlimen berdasarkan tempoh menetap. Berdasarkan Jadual 6 ini jelas menunjukkan bahawa tiada sebarang perubahan yang signifikan bagi tempoh menetap dengan kecenderungan politik di kerusi parlimen. Hal ini kerana responden tetap akan memilih PAS walaupun bagi mereka yang baru dan juga lama menetap di Lembah Klang. Berdasarkan dapatan ini jelas tempoh menetap tidak memberi kesan kepada kecenderungan undi responden di kerusi parlimen.

Jadual 7. Kecenderungan sokongan di peringkat DUN berdasarkan tempoh menetap.

\begin{tabular}{cccccc}
\hline \multirow{2}{*}{ Tempoh Menetap } & \multicolumn{5}{c}{ Kecenderungan Sokongan di Peringkat DUN } \\
\cline { 2 - 6 } & PH & BN & PAS & Bebas & Tidak Mengundi \\
\hline 1-5 tahun & $8(7.1 \%)$ & $20(17.9 \%)$ & $70(62.5 \%)$ & $14(12.5 \%)$ & - \\
6-10 tahun & $8(8.2 \%)$ & $21(21.4 \%)$ & $59(60.2 \%)$ & $8(8.2 \%)$ & $2(2.0 \%)$ \\
$11-15$ tahun & $10(11.2 \%)$ & $12(13.5 \%)$ & $59(66.3 \%)$ & $2(2.2 \%)$ & $6(6.7 \%)$ \\
16-20 tahun & $5(9.6 \%)$ & $14(26.9 \%)$ & $32(61.5 \%)$ & $1(1.9 \%)$ & - \\
Lebih 20 tahun & $4(7.7 \%)$ & $14(26.9 \%)$ & $30(57.7 \%)$ & $4(7.7 \%)$ & - \\
\hline
\end{tabular}

Sumber: Kerja Lapangan 2020

Sementara itu, Jadual 7 adalah berkaitan dengan kecenderungan sokongan di peringkat DUN mengikut tempoh menetap. Berdasarkan dapatan, pola kecenderungan responden diperingkat DUN juga sama dengan parlimen. Di mana tempoh menetap tidak memberi kesan yang signifikan terhadap kecenderungan politik mereka. Jelas bahawa responden kajian ini didapati cenderung untuk mengundi PAS berbanding parti lain.

Pola ini disebabkan kesukaran parti yang lain untuk bersaing dengan PAS kerana rakyat Kelantan telah terbiasa dengan nilai politik Islam PAS dalam kehidupan seharian mereka. Malah politik yang dibawa oleh PAS juga menjadi sebahagian budaya kehidupan seharian masyarakat. Kajian yang dilakukan oleh Muhamad Nadzri, (2020) mendapati Kelantan didominasi oleh PAS dan parti lain sukar menandingi pengaruh PAS disebabkan kecenderungan orang Melayu di Kelantan yang menyukai kepimpinan ulama. Pendidikan dan pergerakan dakwah Islam secara rasmi dan tidak rasmi telah berakar umbi menyebabkan orang Melayu Kelantan beridentifikasi dengan PAS. Kajian oleh Junaidi et al, (2020) pula menunjukkan masyarakat di Pantai Timur 
diasuh sejak dari kecil untuk memilih PAS dan ini menyebabkan mereka menjadi taksub dengan parti tersebut. Hal ini kerana PAS didapati lebih menonjol dalam memperjuangkan agama Islam dan kaum Melayu berbanding parti yang lain. Walaupun UMNO dilihat membela orang Melayu, namun parti itu sangat jarang memperjuangkan isu Islam dengan agresif dan pemimpin UMNO juga tidak dilihat sebagai seorang yang tinggi ilmu agamanya.

Imej Islam yang dibawa oleh PAS telah menambat hati pengundi di Kelantan. Selain itu, ketokohan pemimpin PAS dalam mentadbir negeri seperti bekas Menteri Besar tiada tolok tandingannya oleh mana-mana pemimpin UMNO. Imej pemimpin seperti Nik Abdul Aziz Nik Mat yang tinggi ilmu agamanya, kewarakan, kezuhudan serta keberaniannya dalam menyatakan sesuatu yang haq telah memperkukuhkan lagi pengaruh PAS di Kelantan (Mohd Sayuti, 2003). Kepimpinan yang dimulakan oleh Nik Abdul Aziz Nik Mat diteruskan oleh kepimpinan PAS selepasnya dan ternyata ianya telah meletakkan PAS dalam kedudukan yang selesa di Kelantan. Menurut Mohd Sayuti, (2003) PAS mempunyai dua bentuk pengaruh, iaitu pengaruh daripada ideologi parti dan pengaruh daripada ketokohan pemimpin mereka. Walau bagaimanapun, dalam konteks politik di Kelantan pengaruh PAS dan UMNO didapati sejak dahulu lagi agak seimbang. Namun, faktor yang menentukan kemenangan kedua-dua parti tersebut ialah pengaruh peribadi pemimpin parti tersebut terutama dalam kalangan pengundi atas pagar.

Selain itu, pemimpin PAS terdiri daripada kalangan orang kebanyakan berbeza dengan UMNO pemimpinnya terdiri kalangan yang berstatus elit. PAS menguasai pemimpin peringkat kampung seperti imam, guru-guru agama dan mereka beraliran agama, manakala UMNO pula menguasai golongan atasan dan profesional. Sementara itu, PAS didapati antara parti yang paling efektif dalam menegakkan syiar Islam dan mendapat sokongan yang kuat disebabkan tiga faktor utama, iaitu dasar parti, organisasi dan masyarakat itu sendiri (Syed Husin, 1978).

Sementara itu, pengundi muda kini didapati lebih matang dan lantang bersuara mengenai isu yang dihadapi mereka selain sukar untuk terpengaruh dengan sentimen politik perkauman yang dibawa oleh UMNO (Yazid Saleh et al., 2020). Pemilihan seseorang calon wakil rakyat bukan hanya bergantung kepada faktor personaliti semata-mata, tetapi lebih melebar kepada soal latar belakang calon dan juga parti yang mereka wakili (Yazid Saleh et al., 2020). Trend pengundian orang muda juga banyak dipengaruhi soal yang berkait rapat dengan kepentingan mereka seperti kenaikan kos sara hidup, peluang pekerjaan dan rumah mampu milik.

Kajian Muhamad Nadzri (2009) mendapati terdapat dua jenis perilaku pengundi yang dominan di Malaysia, pertama golongan pengundi yang membuat pilihan secara rasional. Manakala yang kedua, golongan pengundi yang mengidentifikasikan diri mereka kepada parti. Golongan yang mengidentifikasikan diri masih besar jumlahnya, namun pengundi yang membuat pilihan secara rasional juga semakin meningkat. Pemikiran pengundi jenis pilihan secara rasional lebih matang, terbuka dan kritikal dalam membuat pilihan berbanding golongan pengundi yang mengidentifikasikan diri kepada parti politik tertentu. Orang Melayu di Pantai Barat yang terdedah dengan arus permodenan yang tinggi, didapati mereka membentuk pengundi yang membuat pilihan secara rasional (Muhamad Nadzri, 2020).

Secara keseluruhannya pengundi luar Kelantan didapati lebih cenderung menyokong PAS disebabkan oleh nilai politik Islam yang tersemat kukuh dalam budaya politik dan ideologi yang dibawa oleh PAS yang juga menepati aspirasi budaya politik mereka (Mohd Faidz et al., 2014; Mohd Mahadee \& Ab. Bassit, 2008). Selain itu, sokongan dan pendirian politik pengundi luar Kelantan juga didapati dipengaruhi oleh ideologi yang diperjuangkan oleh parti politik (Mohd Mahadee \& Ab. Bassit, 2008) berbanding dengan soal pembangunan (Junaidi, 2017). Sehubungan itu, dapat disimpulkan bahawa tingkah laku politik yang dipamerkan dalam setiap pilihan raya di 
Kelantan adalah jelas menunjukkan bahawa pengundi luar Kelantan setia memilih PAS dengan beridentifikasi diri mereka dengan parti Pas.

\section{Kesimpulan}

Secara keseluruhannya majoriti responden yang dikaji ini terdiri daripada mereka yang tidak menjadi ahli mana-mana parti politik. Selain itu, pengundi luar Kelantan yang menetap di Lembah Klang ini cenderung memilih PAS sebagai parti yang disokong oleh mereka sama ada diperingkat Dun dan Parlimen. Berdasarkan penemuan ini, sentimen keagamaan yang ditanam oleh PAS sejak sekian lama untuk mengikat masyarakat Kelantan dalam pelbagai cara masih mendominasi dan kekal teguh untuk sentiasa menyokong PAS. Nilai yang diperolehi melalui proses sosialisasi yang dilalui oleh mereka sejak kecil lagi masih menjadi keutamaan dalam budaya politik mereka. Hal ini turut dapat dilihat dengan dapatan kajian yang memperlihatkan tempoh menetap di Lembah Klang tidak membezakan pola kecenderungan pengundi luar Kelantan ini. Oleh sebab itu, hasil kajian ini secara amnya dapat menjawab persoalan mengapa pengundi luar Kelantan menjadi sebagai simpanan tetap PAS untuk kekal memerintah Kelantan.

Justeru itu, berdasarkan kepada dapatan kajian ini, parti yang ingin bersaing dengan PAS perlulah memberi perhatian dalam aspek imej Islam dalam perjuangan parti mereka selain menawarkan pakej pembangunan yang seimbang antara dunia dan akhirat kerana isu domestik lain yang menghimpit PAS tetap tidak menjadi keutamaan walaupun ianya adalah penting. Selain itu, pengundi luar Kelantan ini merupakan konfigurasi budaya politik masyarakat Kelantan. Hal ini kerana berdasarkan beberapa penemuan dan kupasan pengkaji lain serta dapatan kajian ini memperlihatkan masyarakat tempatan atau pengundi yang menetap di Kelantan mengambil kira soal isu domestik yang berlaku seperti isu air, kebersihan dan infrastruktur lain namun pengundi luar Kelantan sedikit berbeza kerana isu tersebut bukan lagi keutamaan kerana isu yang berbangkit tidak dirasai mereka yang tinggal di luar Kelantan. Oleh itu, jelaslah bahawa wujud kofigurasi budaya politik pengundi luar Kelantan dalam budaya masyarakat Kelantan berasaskan kecenderungan politik mereka. Dengan ini, nyatalah bahawa kecenderungan politik pengundi luar Kelantan yang lebih berpihak kepada PAS disebabkan mereka telah beridentifikasi diri terhadap parti Pas. Proses sosialisasi secara berterusan dengan penerapan nilai Islam oleh kerajaan Kelantan yang dipimpin oleh Pas telah mengikat diri mereka dengan imej Islamik yang dipamerkan oleh Pas.

\section{Rujukan}

Ab. Rahim Tahir. (1995). Analisis 95 Perangkap BN Tahun 2,000. Ampang: Cita khidmat (M). Sdn. Bhd.

Amer Saifude Ghazali. (2013). Politik Pilihan Raya dan Gelagat Pengundian Pada Pilihan Raya Umum Ke-12 Di Kelantan. Tesis PhD, Universiti Malaya.

Ghazali Mayudin. (2006). Demokrasi dan Pilihan Raya di Malaysia. Dlm. Ghazali Mayudin (pytn).

Demokrasi, Kepimpinan dan Keselamatan Dalam Politik Malaysia. Bangi: Penerbit Universiti Kebangsaan Malaysia.

Imai, K., \& King, G. (2004). Did Illegal Overseas Absentee Ballots Decide the 2000 U.S. Presidential Election? Perspectives on Politics, Symposium, 2(3), 537-549. 
Jaca, G. B., \& Torneo, A. R. (2019). Explaining (non) participation in overseas voting: the case of overseas Filipino voters in Japan in the 2016 elections. Diaspora Studies, 1-30.

Junaidi Awang Besar, Muhammad Hazim Abdul Ghani, Mohd Fuad Mat Jali \& Novel Lyndon. (2015). Pola politik kaum dalam pilihan raya umum Malaysia ke-13: Kajian kes negeri Selangor. Geografia-Malaysian Journal of Society and Space, 11(9), 99-111.

Junaidi Awang Besar, Nur Ellyanis Mohd Basori \& Mohd Syukri Zainuddin. (2020). Pola Sokongan Belia Melayu Dalam PRU-14 di Beberapa DUN Terpilih Dalam Negeri Kedah. Geografia-Malaysia Journal of Society and Space, 16(4), 150-163.

Junaidi Awang Besar, Nur Ellyanis Mohd Basori \& Muhammad Hazim Abdul Ghani. (2020). Prestasi dan penerimaan pengundi terhadap Parti Islam Semalaysia (PAS) dalam Pilihan Raya Umum ke-14 di wilayah Pantai Barat semenanjung Malaysia. e-Bangi Journal of Social Sciences and Humanities, 17(4), 60-77.

Junaidi Awang Besar. (2017). Tingkah laku pengundi dan pilihan politik di kawasan Parlimen Pasir Mas, Kelantan. Geografia-Malaysia Journal of Society and Space, 13(3), 97-111.

Junaidi Awang Besar. (2019). Perubahan Politik Dalam Pilihan Raya Umum (PRU) ke-14, 2018 di Malaysia. Geografia-Malaysian Journal of Society and Space, 15(4), 220-232.

Junaidi Awang Besar. (2021). Sentimen Kepartian dan Personaliti Pemimpin Pada Pilihan Raya Umum 2018: Kajian di Kawasan di DUN Chempaka, Kelantan. Akademika, 91(1), 81-96.

Krejcie, V. R., \& Morgan, D. W. (1970). Determining Sample Size for Research Activities. Educational and Psychological Measurement, 30: 607-619.

Mazlan Ali. (1998). Hubungan Semangat 46 dan PAS 1988-1996, Satu Tinjauan Terhadap Politik Malaysia. Tesis Sarjana. Universiti Malaya.

Mohd Agus Yusoff \& Shah Mohd Akmal Abdul Halim. (2019). Tingkah Laku Pengundi Felda Dalam PRU-14: Identifikasi Parti, Sosiologikal atau Pilihan Rasional. Akademika, 89(3), 167-182.

Mohd Faidz Mohd Zain, Samsul Adabi Mamat, Junaidi Awang Besar \& Mohd Fuad Mat Jali. (2014). Pilihan Raya Umum 2013: Penolakan berterusan pengundi di Kelantan terhadap Barisan Nasional. Geografia-Malaysian Journal of Society and Space, 10(4), 15-27.

Mohd Fuad Mat Jali, Junaidi Awang Besar, Rosmadi Fauzi, Amer Saifude Ghazali, Novel Lyndon \& Mazlan Ali. (2012). Politik bandar: Persepsi dan tingkah laku politik pengundi di kawasan parlimen Petaling Jaya Selatan dan Batu. Akademika, 82(3), 61-75.

Mohd Hariszuan Jaharudin. (2014). Pilihan Raya Umum Ke-13: Perubahan budaya politik Malaysia dan krisis legitimasi moral Barisan Nasional. Kajian Malaysia, 32(2), 149-169.

Mohd Mahadee Ismail, Azlina Abdullah, Nor Azlili Hassan \& Mohd Sabri Md Nor. (2020). Perkembangan Politik Era Malaysia Baharu: Pandangan Eksklusif Belia Terpelajar. Akademika, 90(Isu Khas 1/Special Issue), 161-174.

Mohd Mahadee Ismail., \& Ab Bassit Husin. (2008). Demokrasi dalam Pilihan Raya Umum ke-12: Satu tinjauan ke atas budaya politik masyarakat Melayu Kelantan. Seminar Politik Malaysia: Shah Alam. Mac 2008, hlm. 228-241.

Mohd Sayuti Omar. (2003). Undurkan Mahathir Dilema Dollah Badawi. Kuala Lumpur: Tinta Merah.

Muhamad Nadzri Mohamed Noor. (2009). Politik Malaysia di Persimpangan Praktik Politik dalam PRU 2008 dan Kontemporari. Petaling Jaya: Strategic Information and Research Development Centre. 
Muhamad Nadzri Mohamed Noor. (2020). Pilihan raya dan politik Malaysia pasca PRU 2018:

Persaingan, dinamik dan implikasi. Jebat: Malaysian Journal of History, Politics \& Strategic Studies, 47(1), 150-175.

Nazri Noor. (2015). Badi PRU 2004 berulang di Kelantan. The Malaysian Insider. 23 Disember: 1.

Riduan Mohamad Nor. (2015). Tribut buat sang pencerah. Kuala Lumpur: JUNDI Resources.

Sebastián U. de Reguero \& Régis Dandoy. (2021). Should We Go Abroad? The Strategic Entry of Ecuadorian Political Parties in Overseas Electoral Districts. Journal of Representative Democracy, 1-18.

Shukeri Mohamad, Mohamad Azrien Mohamed Adnan, Syed Abdurahman Syed Hussin. (2011). Analisis Pengaruh Politik Islam di Negeri Kelantan Terhadap Gaya Hidup Masyarakat di Malaysia. Dlm. Ahmad Zaki Berahim (pnyt). World Congress for Islamic History and Civilization, Tajdid \& Islah, hlm. 1-31. Kuala Lumpur: Universiti Malaya.

Simone Battiston, \& Bruno Mascitelli. (2008). The challenges to democracy and citizenship surrounding the vote to Italians overseas, Modern Italy, 13(3), 261-280.

Syed Husin Ali. (1978). Kemiskinan dan Kelaparan Tanah di Kelantan. Petaling Jaya: Karangkraf. Sdn. Bhd.

Syed Husin Ali. (2008). Orang Melayu: Masalah dan Masa Depan. Kuala Lumpur: Harakah.

Wan Nik Wan Yussof. (2015). Legasi Tok Guru Politik dan Dakwah. Kota Bharu: Pusat Kajian Strategik Negeri Kelantan.

Yazid Saleh, Siti Noranizahhafizah Boyman, Hanifah Mahat, Mohmadisa Hashim, Nasir Nayan, Saiyidatina Balkhis Norkhaidi, \& Samsudin Suhaili. (2020). Pola sokongan pengundi muda sebelum Pilihan Raya Umum ke 14 di Malaysia. Geografia-Malaysian Journal of Society and Space, 16(1), 80-94.

Zaini Othman. (2014). Demokrasi di negara sedang membangun: Pengalaman Asia Tenggara. Dlm. Ghazali Mayudin, Jamaie Hamil, Sity Daud \& Zaini Othman (pnyt.). Demokrasi Kepimpinan \& Keselamatan dalam Politik Malaysia. Bangi: Penerbit Universiti Kebangsaan Malaysia. 